University of Massachusetts Amherst

ScholarWorks@UMass Amherst

1997

\title{
Towards Speciation of Arsenic in a Standard Reference River Sediment by High-performance Ion Chromatography Coupled with Plasma Source Mass Spectrometry
}

Peter Michael Yehl

University of Massachusetts Amherst

Julian Tyson

University of Massachusetts Amherst

Follow this and additional works at: https://scholarworks.umass.edu/chem_faculty_pubs

Part of the Chemistry Commons

\section{Recommended Citation}

Yehl, Peter Michael and Tyson, Julian, "Towards Speciation of Arsenic in a Standard Reference River Sediment by High-performance Ion Chromatography Coupled with Plasma Source Mass Spectrometry" (1997). Analytical Communications. 1371.

Retrieved from https://scholarworks.umass.edu/chem_faculty_pubs/1371 


\title{
Towards Speciation of Arsenic in a Standard Reference River Sediment by High-performance lon Chromatography Coupled With Plasma Source Mass Spectrometry
}

\author{
Peter M. Yehl and Julian F. Tyson \\ Department of Chemistry, University of Massachusetts, Box 34510, Amherst, MA 01003-4510, \\ USA
}

\begin{abstract}
A procedure for the extraction and separation of alkylarsenic species from Buffalo River Sediment standard reference material has been developed. The sample was sonicated in methanol-hydrochloric acid-water $(50+10+40 \mathrm{v} / \mathrm{v})$ and filtered. The arsenic species in the extract were separated by anion exchange HPLC, on a Hamilton PRP X-100 column, using phosphate (pH 6.0) and citrate (pH 6.0) buffers as eluents, and detected by direct aspiration into an inductively coupled plasma mass spectrometer. Monomethylarsonic acid, at a concentration of about $0.2 \mathrm{mg} \mathrm{kg}^{-1}$ in the solid, was detected.
\end{abstract}

In studies of the fate of inorganic contaminants introduced into soils and sediments, it is clear that procedures capable of determining alkylated (in particular methylated) forms of the elements are needed. Methylated forms of mercury and tin have been found in river sediments ${ }^{1}$ and lake sediments, ${ }^{2}$ respectively. Microbes in anaerobic and aerobic environments have the ability to alkylate metals and metalloids, ${ }^{3-5}$ although the mechanisms of alkylation are largely unknown. Though considered less toxic than their inorganic derivatives, ${ }^{6}$ much less is known about the organic forms of arsenic and the pathways by which they are formed from inorganic precursors.

The provision of reliable information about arsenic speciation underpins toxicological studies, $, 7,8$ studies of the uptake and incorporation of arsenic by plants, ${ }^{9}$ studies of the fate of arsenic introduced into the environment by the use of products such as pressure-treated timber ${ }^{10}$ and studies of microbial transformations.

As soils and sediments are composed largely of silicates and other naturally adsorbing oxides, they have the ability to accumulate arsenic and other toxic elements. ${ }^{11,12}$ As a result of the uptake of inorganic arsenic by microbes, biological transformation to alkylarsenic species may occur. Arsenic species have been determined in a synthetic fish matrix, ${ }^{13}$ urine, ${ }^{14,15}$ various aquatic life forms ${ }^{16,17}$ and in standard reference waters. ${ }^{18}$ Arsenic species determinations have been conducted with improved sensitivity, ${ }^{18,19}$ but so far there have been no reports of alkylarsenic species in soils or sediments. Hansen et al. described an HPLC-ICP-MS method, capable of detecting methylated arsenic species in the presence of inorganic arsenic, which was applied to the analysis of extracts of soil from a site contaminated by arsenic from a timber preservative. ${ }^{20}$ However, no such species were detected. The detection limit for both monomethyl and dimethyl species was $3 \mathrm{ng} \mathrm{ml}^{-1}$ in the extract based on a $100 \mu \mathrm{l}$ injection volume.

To validate this analytical methodology, standard reference materials are required. As a first step towards the provision of such reference materials, we have examined an existing standard reference material (Buffalo River Sediment) for its methylated arsenic content. This material was chosen because firstly it has a relatively high total arsenic content (23.4 $\mathrm{mg} \mathrm{kg}{ }^{-1}$ ) and secondly the anaerobic environment from which the material was collected could lead to biological transformation and the production of organoarsenic species.

A major challenge in the speciation of trace components in solid samples is the removal of the analytes from the matrix quantitatively, without changing the relative concentrations of the individual species. Contaminants in soils and sediments are likely to be predominantly on the surface of the matrix particles, and can therefore be removed by simple liquid extraction procedures. In this paper we have examined the feasibility of a procedure based on sonication of the sample in methanolic hydrochloric acid.

\section{Experimental}

\section{Apparatus}

An HPLC system was constructed from a Waters (Milford, MA, USA) Model M-6000 dual-piston HPLC pump, a VICI (Houston, TX, USA) six-port rotary injection valve with an external loop [made of Cheminert polyether ether ketone (PEEK)], a Hamilton (Reno, NV, USA) PRP-X100 anion exchange column $(4.1 \mathrm{~mm}$ id, $150 \mathrm{~mm}$ length, $10 \mu \mathrm{m}$ particle size) equipped with a $10 \mathrm{~mm}$ Hamilton PRP-X100 guard with a Hamilton column/cartridge assembly, and a Perkin-Elmer SCIEX (Norwalk, CT, USA) ELAN 5000 inductively coupled plasma mass spectrometer detector. The interface to the instrument was constructed by connecting PEEK tubing $(0.010$ in id) from the column outlet to a wider bore Teflon tubing, then directly inserting the uptake line of a cross-flow nebulizer into the Teflon. Samples were sonicated in a E/MC, Model 450, ultrasonic bath. The operating conditions of the plasma source mass spectrometer are given in Table 1 .

\section{Data processing}

Data were collected using the ELAN software on an IBM 386DX2 personal computer. Data were transferred from the PC hard drive to a floppy disk and reprocessed with a spreadsheet (Microsoft Excel). Five point data smoothing was used.

Table 1 Plasma operating conditions

$\begin{array}{ll}\text { Plasma power } & 1000 \mathrm{~W} \\ \text { Auxiliary gas flow } & 0.81 \mathrm{~min}^{-1} \\ \text { Carrier gas flow } & 1.01 \mathrm{~min}^{-1} \\ \text { Coolant flow } & 151 \mathrm{~min}^{-1} \\ \text { Dwell time } & 125 \mathrm{~ms} \\ \text { Mass:charge } & 75 \\ \text { Acquisition frequency } & 8 \mathrm{~Hz} \\ \text { Mode of monitoring } & \text { Continuous }\end{array}$




\section{Standards and Reagents}

Stock solutions containing $100 \mathrm{mg} \mathrm{dm}^{-3}$ of arsenic were prepared for each standard. For the monomethylarsonic acid (MMA) standard, $0.3371 \mathrm{~g}$ of $\mathrm{CH}_{3} \mathrm{AsBr}_{2}$ (Alfa Aesar, 98\% pure, Ward Hill, MA, USA) liquid was weighed out in a ventilated hood. The solution was diluted to $1.000 \mathrm{dm}^{3}$ with $18.0 \mathrm{~m} \Omega \mathrm{cm}$ deionized (E-pure purification system, Barnstead Inc., Dubuque, IA, USA) water. For the dimethylarsenic acid (DMA) standard, $0.2915 \mathrm{~g}$ of $\mathrm{C}_{2} \mathrm{H}_{6} \mathrm{AsNaO}_{2} \cdot 3 \mathrm{H}_{2} \mathrm{O}$ (Fluka, $98 \%$ purity, Buchs, Switzerland) was weighed and diluted to 1.000 $\mathrm{dm}^{3}$ with deionized water. The As ${ }^{\mathrm{III}}$ standard was made by weighing $0.1737 \mathrm{~g}$ of $\mathrm{NaAsO}_{2}$ (Mallinckrodt, St. Louis, MO, USA) and diluting to $1.000 \mathrm{dm}^{3}$, and the $\mathrm{As}^{\mathrm{V}}$ standard was made by weighing $0.4164 \mathrm{~g}$ of $\mathrm{Na}_{2} \mathrm{HAsO}_{4} \cdot 7 \mathrm{H}_{2} \mathrm{O}$ (Fisher, Fairlawn, NJ, USA) and diluting to $1.000 \mathrm{dm}^{3}$. The HPLC mobile phases used were: (a) $5.0 \mathrm{~mm}$ phosphate buffer $\mathrm{pH} 6.0$ (BDH AnalaR grade, Merck, Poole, England); and (b) $10.0 \mathrm{~mm}$ citrate buffer pH 6.0 (Fisher). The extraction solution was prepared by adding $10.0 \mathrm{ml}$ of concentrated hydrochloric acid (Fisher, certified ACS Plus) to $50.0 \mathrm{ml}$ of methanol (Fisher, HPLC grade), and diluting to $100 \mathrm{ml}$ with deionized water.

\section{Procedures}

\section{Extraction}

A 1 g sample of SRM 2704 (Buffalo River Sediment, NIST, Gaithersburg, MD, USA) was weighed into an acid-washed 25 $\mathrm{ml}$ Erlenmeyer flask for extraction. Ten millilitres of the extraction solution were added to the sample. The sample was swirled to promote mixing, and then sonicated for $90 \mathrm{~min}$ at full power. The resulting mixture was vacuum filtered through rinsed qualitative filter-paper (Whatman no. 1) into a $25 \mathrm{ml}$ filter flask, transferred to a $25 \mathrm{ml}$ calibrated flask, and made up to volume with deionized water.

\section{Separation}

For the $500 \mathrm{ng} \mathrm{ml}^{-1}$ standards, a $20 \mu \mathrm{l}$ volume was injected into the phosphate buffer flowing at $1.0 \mathrm{ml} \mathrm{min}-1$. After $3 \mathrm{~min}$, the mobile phase was changed to the citrate buffer, and after 5 min, the flow was stepped to $2.0 \mathrm{ml} \mathrm{min}-1$. For the Buffalo River Sediment extracts, the same size sample was injected into the phosphate buffer mobile phase. After $5 \mathrm{~min}$, the flow rate was stepped to $2.0 \mathrm{ml} \mathrm{min}-1$. No citrate buffer was used in the separation of the arsenicals in the extracts, as this requires long re-equilibration times on switching back to phosphate. The use of the $\mathrm{pH} 6.0$ phosphate buffer was first proposed by Rubio et $a l .{ }^{13}$

\section{Method Development}

As this was a preliminary study, neither extraction solvent composition nor sonication period were fully optimized. The chromatographic separation was based on that described by Rubio et al..$^{13}$ and only minor further optimization studies were performed. The effects of mobile phase flow rate and the time of citrate introduction were optimized. Both $1.0 \mathrm{ml} \mathrm{min}^{-1}$ and 2.0 $\mathrm{ml} \mathrm{min}-1$ were investigated, and the switch to the citrate mobile phase was investigated at every 1 min between 2 and 6 min. Various concentrations of phosphate were investigated, including 5,10 and $20 \mathrm{~mm}$, and both 5 and $10 \mathrm{~mm}$ citrate were studied. Equilibration times after changing back to phosphate following a citrate run were varied from 10 to $40 \mathrm{~min}$. The effect of chloride was investigated because the only isobaric interference for the determination as As $(\mathrm{m} / \mathrm{z}=75)$ by plasma source mass spectrometry is that of $\mathrm{ArCl}^{+}$, an ion which produced an equivalent As concentration, for the direct aspiration of a $1.0 \%$ $\mathrm{Cl}^{-}$solution, of approximately $2.9 \mathrm{ng} \mathrm{ml}^{-1}$ with the instrument and operating conditions used in this study.

\section{Results and Discussion}

\section{Method Development}

As the column eluent was directly aspirating into the mass spectrometer, a slightly lower concentration of the phosphate mobile phase $(5.0 \mathrm{~mm})$ than had been used by previous investigators ${ }^{13}$ was chosen to prevent degradation of the nickel sampler and skimmer cones. The dominant extractable forms of arsenic in this experiment were As ${ }^{\mathrm{III}}$, MMA and $\mathrm{As}^{\mathrm{V}}$. Using solely a phosphate mobile phase, the capacity factor for $\mathrm{As} v$ was moderately high $(>25)$ and could interfere with subsequent determinations. The citrate buffer, which was introduced as the mobile phase after $3 \mathrm{~min}$, affected the retention of only inorganic $\mathrm{As}^{\mathrm{V}}$.

\section{Analysis of SRM 2704}

The chromatogram of the standards is shown in Fig. 1, from which it can be seen that arsenate is the only compound affected by the switch to the citrate mobile phase. The identities of the peaks were assigned by matching with the retention times of single species chromatograms. A chromatogram of the extract from the sediment sample is shown in Fig. 2, from which the presence of monomethylarsenic can be clearly seen. This peak



Fig. 1 Chromatogram of $0.500 \mu \mathrm{g} \mathrm{ml}^{-1}$ arsenic standards. 1, inorganic arsenite as $\mathrm{AsO}_{2}{ }^{-}$; 2, DMA; 3, MMA; 4, inorganic arsenate as $\mathrm{AsO}_{4}{ }^{3-}$. Separation carried out on a Hamilton PRP-X100 anion exchange column $(150 \mathrm{~mm} \times 4.1 \mathrm{~mm}$ id, particle size $10 \mu \mathrm{m})$ with a mobile phase of $\mathrm{pH} 6.0$ phosphate, $1.0 \mathrm{ml} \mathrm{min}^{-1}$ for $3 \mathrm{~min}$ followed by pH 6.0 citrate, $1.0 \mathrm{ml} \mathrm{min}-1$

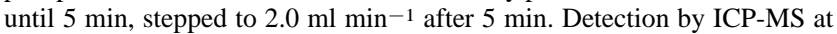
$m / z$ 75. Injection volume was $20 \mu 1$. Inorganic $\mathrm{As}^{\mathrm{V}}$ is the only ion affected by citrate mobile phase.

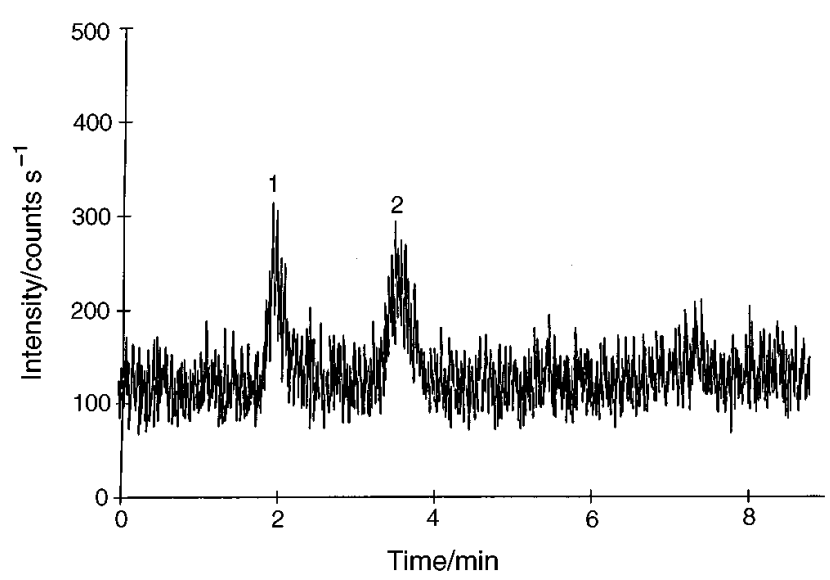

Fig. 2 Chromatogram of Buffalo River Sediment extract. 1, unretained As, (including inorganic As ${ }^{I I I}$ ); 2, MMA. Separation carried out on a Hamilton PRP-X100 anion exchange column with a mobile phase of $\mathrm{pH} 6.0$ phosphate, $1.0 \mathrm{ml} \mathrm{min}^{-1}$ for $5 \mathrm{~min}$, stepped to $2.0 \mathrm{ml} \mathrm{min}-1$ after $5 \mathrm{~min}$. Detection by ICP-MS at $m / z 75$. Injection volume was $20 \mu$ l. Inorganic $\mathrm{As} v$ did not elute until $14 \mathrm{~min}$. 
cannot be due to an $\mathrm{ArCl}$ interference as the concentration of $\mathrm{Cl}$ at the peak maximum, allowing for an on-column dilution of $\times 15$ (estimated from the basewidth of peak 2), is about 1000 $\mu \mathrm{g} 1^{-1}$, which would produce a signal equivalent to that of 0.3 $\mathrm{ng} \mathrm{ml} \mathrm{m}^{-1}$ or 4 counts $\mathrm{s}^{-1}$ at this position in the chromatogram. As the peak to peak noise is about 50 counts $\mathrm{s}^{-1}$, it can be concluded that the concentration of chloride is too low to produce a measurable signal at this position in the chromatogram. The extraction procedure employed in this analysis was not quantitative for total arsenic, as only $5-10 \%$ of the total arsenic was accounted for in the chromatogram when the height of the $\mathrm{As}^{\mathrm{V}}$ peak was measured, and thus the procedure might not be quantitative for all alkylated forms of arsenic. However, experiments in progress show that quantitative recoveries of spikes of methylated arsenic species are obtained, indicating that $(a)$ this procedure may be quantitative for methylated As species, and $(b)$ there is no degradation of these species due to the extraction procedure. Although precise quantification was not attempted in this preliminary study, it was found that the peak height response was a linear function of concentration and so the peak height values obtained in Figs. 1 and 2 could be used to estimate that MMA was present at a concentration range of at least $0.2 \mathrm{mg} \mathrm{kg}^{-1}$ in the solid. All the unretained arsenic species, which include arsenite, are eluted at approximately 2.0 min, the column void volume. Inorganic $\mathrm{As}^{\mathrm{V}}$ eluted at approximately $14 \mathrm{~min}$. Detection limits based on peak heights can be estimated from the chromatograms as the concentration injected in $20 \mu \mathrm{l}$, giving a peak height equal to twice the peak to peak noise of 50 counts $\mathrm{s}^{-1}$. For the MMA species, the detection limit is estimated to be $8 \mathrm{ng} \mathrm{ml}^{-1}$.

It is suggested that the extraction technique employed in this preliminary work operates by ion pairing and/or ion exchange mechanisms. A protonated methanol species could be formed which had the ability to form ion pairs with anions in the sample. Additionally, chloride ions could displace anionic arsenic species from cationic binding sites on the solid surface.

\section{Conclusions}

The presence of a methylated arsenic species in a standard reference material has been demonstrated with a simple ultrasound-aided extraction. Further validation studies are needed and these are in progress, based on the recoveries of arsenic species spiked into the sample and also comparison with the results of other extraction procedures, including microwaveassisted extraction and supercritical fluid extraction. Phosphorus compounds, which resemble structurally the arsenic compounds of interest here, have been efficiently extracted from soils using microwave assisted extraction. ${ }^{21}$ Quantification of the arsenic species will require increased sensitivity, as the concentrations of the arsenic species in the extract are near the detection limit, as may be seen from Fig. 2. One approach, currently under study, is the development of a more sensitive mode of sample introduction to the spectrometer based on post- column chemical vapor generation with sodium tetrahydroborate. It is thought that a sensitivity improvement by up to two orders of magnitude, depending upon the species, may be possible.

The authors thank Dr. M. K. Behlke and Dr. S. Wise for the provision of the Buffalo River Sediment standard reference material, Dr. P. C. Uden for the use of the HPLC pump and many helpful discussions, and the Perkin-Elmer Corporation for the provision and maintenance of the plasma source mass spectrometer.

\section{References}

1 Jantzen, G., and Prange, A., Fresenius' J. Anal. Chem., 1995, 353, 28.

2 Mueller, M. D., Fresenius' Z. Anal. Chem., 1984, 317, 32.

3 Hiroki, M., and Yoshiwara, Y., Soil Sci. Plant Nutr., 1993, 39, 237.

4 Krishnamurthy, S., J. Chem. Educ., 1992, 69, 347.

5 Hanoaka, K., Tagawa, S., and Kaise, T., Appl. Organomet. Chem., 1992, 6, 139.

6 Yamauchi, H., and Fowler, B., in As in the Environ., Pt. II: Human Health and Ecosystem Effects, ed. Nriagu, J., 1994, p. 35.

7 Naqui, S. M., Vauishnaui, C., and Singh, H., in As in the Environ, Pt. II: Human Health and Ecosystem Effects, ed. Nriagu, J., 1994, p. 55.

8 Ymanka, K., Ohba, H., Hasegawa, A., Sawamura, R., and Okada, S., Biochem. Biophys. Res. Commun., 1989, 165, 43.

9 Adriano, D. C., Trace Elements in the Terrestrial Environment, Springer-Verlag, New York, 1986.

10 Weis, P., and Weis, J., J. Exp. Mar. Biol., 1992, 161, 189.

11 Weis, J., and Weis, P., Mar. Ecol. Prog. Ser., 1992, 83, 45

12 Weis, P., Weis, J., and Proctor, T., Estuarine, Coast. Shelf Sci., 1993, 36, 71 .

13 Rubio, R., Padro, A., Alberta, J., and Rauret, G., Microchim. Acta, 1992, 109, 39.

14 Heitkemper, D., Creed, J., Caruso, J., and Fricke, F. L., J. Anal. At Spectrom., 1989, 4, 279.

15 Larsen, E. H., Pritzl, G., and Hansen, S. H., J. Anal. At. Spectrom., 1993, 8, 557.

16 Shibata, Y., and Morita, M., Appl. Organomet. Chem., 1992, 6, 343.

17 Vélez, D., Ybáñez, N., and Montoro, R., J. Anal. At. Spectrom., 1996, 11, 271.

18 Magnuson, M. L., Creed, J. T., and Brockhoff, C. A., J. Anal. At. Spectrom., 1996, 11, 893.

19 Galier, J., and Irgolic, K. J., Appl. Organomet. Chem., 1994, 8, 129.

20 Hansen, S. H., Larsen, E. H., Pritzl, G., and Cornett, C., J. Anal. At. Spectrom., 1992, 7, 629.

21 Degeus, H., Zegers, B. N., Lingeman, H., and Brinkman, U. A. T., Int. J. Environ. Anal. Chem., 1994, 56, 119. 